Prepared in cooperation with the Houlton Band of Maliseet Indians

\title{
Evaluation of Aerial Thermal Infrared Remote Sensing to Identify Groundwater-Discharge Zones in the Meduxnekeag River, Houlton, Maine
}

Open-File Report 2013-1168 
THIS PAGE INTENTIONALLY LEFT BLANK 


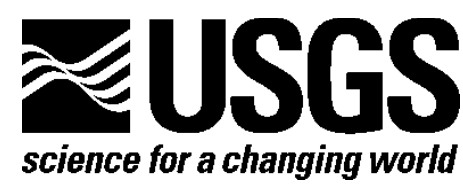

Prepared in cooperation with the Houlton Band of Maliseet Indians

\section{Evaluation of Aerial Thermal Infrared Remote Sensing to Identify Groundwater-Discharge Zones in the Meduxnekeag River, Houlton, Maine}

By Charles W. Culbertson, Thomas G. Huntington, James M. Caldwell, and Cara O'Donnell

Open-File Report 2013-1168

U.S. Department of the Interior

U.S. Geological Survey 


\section{U.S. Department of the Interior \\ SALLY JEWELL, Secretary}

\section{U.S. Geological Survey \\ Suzette M. Kimball, Acting Director}

U.S. Geological Survey, Reston, Virginia: 2014

For more information on the USGS-the Federal source for science about the Earth, its natural and living resources, natural hazards, and the environment-visit http://www.usgs.gov or call 1-888-ASK-USGS

For an overview of USGS information products, including maps, imagery, and publications, visit http://www.usgs.gov/pubprod

To order this and other USGS information products, visit http://store.usgs.gov

Suggested citation:

Culbertson, C.W., Huntington, T.G., Caldwell, J.M., and O'Donnell, Cara, 2014, Evaluation of aerial thermal infrared remote sensing to identify groundwater-discharge zones in the Meduxnekeag River, Houlton, Maine: U.S. Geological Survey Open-File Report 2013-1168, 21 p., http://dx.doi.org/10.3133/ofr20131168.

Any use of trade, product, or firm names is for descriptive purposes only and does not imply endorsement by the U.S. Government.

Although this information product, for the most part, is in the public domain, it also may contain copyrighted materials as noted in the text. Permission to reproduce copyrighted items must be secured from the copyright owner.

ISSN 2331-1258 (online) 


\section{Acknowledgments}

The authors thank Larry Davis, Davis Aviation, Kent, Ohio, for performing the aerial surveys and collecting and analyzing the aerial infrared videography. 


\section{Contents}

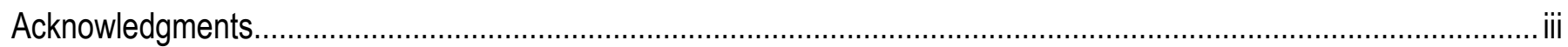

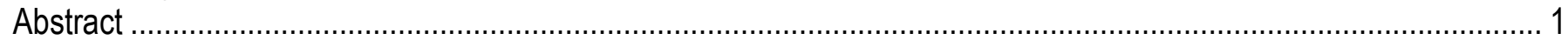

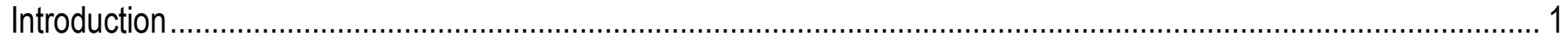

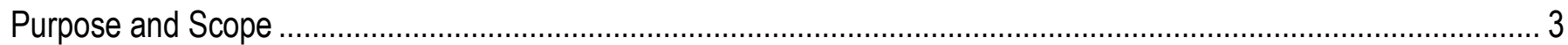

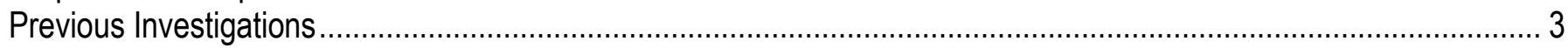

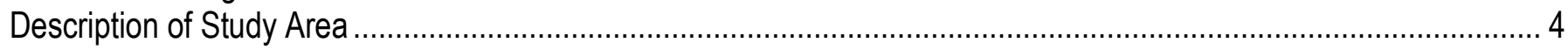

Aerial and Ground-Based Methods of Data Collection ................................................................................ 5

TIR Remote Sensing of Surface-Water Temperature Anomalies ................................................................... 5

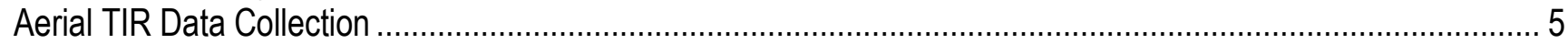

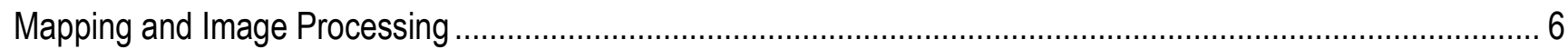

Characterization and Ground Verification of Aerially Identified Thermal Anomalies.............................................. 6

Identification of Thermal Anomalies....................................................................................................

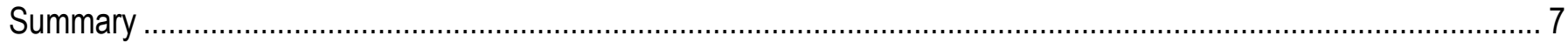

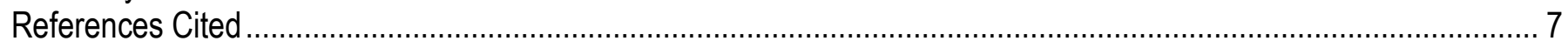

\section{Figures}

Figure 1. Map showing hydrography of the Meduxnekeag River watershed in northeastern Maine.

Figure 2. Map showing locations of USGS streamgages and sampling stations in the Meduxnekeag River watershed near Houlton in northeastern Maine.

Figure 3. Map showing land use in the Meduxnekeag River watershed near Houlton in northeastern Maine.

Figure 4. Map showing topography and hydrography of the Meduxnekeag River watershed near Houlton in northeastern Maine...

Figure 5. Map showing surveillance reaches along the Meduxnekeag River near Houlton, Maine, in the aerial thermal-imaging study on A, December 3-4, 2003, and B, November 26, 2004.

Figure 6. Images of thermal anomalies for discharges into the Meduxnekeag River near Houlton, Maine, during the A, December 3-4, 2003, flight and the B, November 26, 2004, flight.

\section{Tables}

Table 1. Thermal anomalies identified in the Meduxnekeag River near Houlton, Maine, during a flight on December 3 from 23:45 to 4:30 Eastern Standard Time on December 4, 2003.

Table 2. Thermal anomalies identified in the Meduxnekeag River near Houlton, Maine, during a flight on November 26, 2004, from 19:14 to 23:02 Eastern Standard Time. 


\section{Conversion Factors, Datum, and Abbreviations}

Inch/Pound to SI

\begin{tabular}{lcl}
\hline \multicolumn{1}{c}{ Multiply } & By & \multicolumn{1}{c}{ To obtain } \\
\hline inch (in.) & Length & \\
inch (in.) & 2.54 & centimeter $(\mathrm{cm})$ \\
foot (ft) & 25.4 & millimeter $(\mathrm{mm})$ \\
mile (mi) & 0.3048 & meter $(\mathrm{m})$ \\
\hline & 1.609 & kilometer $(\mathrm{km})$ \\
\hline acre & Area & \\
acre & 4,047 & square meter $\left(\mathrm{m}^{2}\right)$ \\
square foot $\left(\mathrm{ft}^{2}\right)$ & 0.004047 & square $\mathrm{kilometer}\left(\mathrm{km}^{2}\right)$ \\
square mile $\left(\mathrm{mi}^{2}\right)$ & 0.09290 & square meter $\left(\mathrm{m}^{2}\right)$ \\
& 2.590 & square $\mathrm{kilometer}\left(\mathrm{km}^{2}\right)$ \\
\hline cubic foot per second $\left(\mathrm{ft}^{3} / \mathrm{s}\right)$ & Flow rate & \\
cubic foot per second $\left(\mathrm{ft}^{3} / \mathrm{s}\right)$ & 0.02832 & cubic meter per second $\left(\mathrm{m}^{3} / \mathrm{s}\right)$ \\
\hline
\end{tabular}

Temperature in degrees Celsius $\left({ }^{\circ} \mathrm{C}\right)$ may be converted to degrees Fahrenheit $\left({ }^{\circ} \mathrm{F}\right)$ as follows: ${ }^{\circ} \mathrm{F}=\left(1.8 \times{ }^{\circ} \mathrm{C}\right)+32$

Temperature in degrees Fahrenheit $\left({ }^{\circ} \mathrm{F}\right)$ may be converted to degrees Celsius $\left({ }^{\circ} \mathrm{C}\right)$ as follows: ${ }^{\circ} \mathrm{C}=\left({ }^{\circ} \mathrm{F}-32\right) / 1.8$

Vertical coordinate information is referenced to the North American Vertical Datum of 1988 (NAVD 88).

Horizontal coordinate information is referenced to the North American Datum of 1983 (NAD 83).

Altitude, as used in this report, refers to distance above the vertical datum.

Wavelengths of thermal radiation bands are measured in micrometers $(\mu \mathrm{m})$.

The resistance of the thermal imager is given in ohms $(\Omega)$.

\section{Abbreviations}

$\begin{array}{ll}\text { AIDIA } & \text { aerial infrared digital imaging analysis } \\ \text { DDT } & \text { dichloro-diphenyl-trichloroethane } \\ \text { DEP } & \text { Department of Environmental Protection } \\ \text { GPS } & \text { global positioning system } \\ \text { HBMI } & \text { Houlton Band of Maliseet Indians } \\ \text { TIR } & \text { thermal infrared } \\ \text { USGS } & \text { U.S. Geological Survey } \\ \text { VED } & \text { video encoder-decoder }\end{array}$




\title{
Evaluation of Aerial Thermal Infrared Remote Sensing to Identify Groundwater-Discharge Zones in the Meduxnekeag River, Houlton, Maine
}

\author{
By Charles W. Culbertson'1, Thomas G. Huntington'1, James M. Caldwell', and Cara O'Donnell ${ }^{2}$
}

\begin{abstract}
Residents of the area near Houlton, Maine, have observed seasonal episodic blooms of algae and documented elevated concentrations of fecal-coliform bacteria and inorganic nutrients and low dissolved oxygen concentrations in the Meduxnekeag River. Although point and nonpoint sources of urban and agricultural runoff likely contribute to water-quality impairment, the role of shallow groundwater inflows in delivering such contaminants to the Meduxnekeag River has not been well understood.

To provide information about possible groundwater inflows to the river, airborne thermal infrared videography was evaluated as a means to identify and classify thermal anomalies in a 25-mile reach of the mainstem and tributaries of the Meduxnekeag River near Houlton, Maine. The U.S. Geological Survey, in cooperation with the Houlton Band of Maliseet Indians, collected thermal infrared images from a single-engine, fixed-wing aircraft during flights on December 3-4, 2003, and November 26, 2004.

Eleven thermal anomalies were identified on the basis of data from the December 2003 flight and 17 from the November 2004 flight, which covered the same reaches of stream. Following image analysis, characterization, and prioritization, the georeferenced infrared images of the thermal anomalies were compared to features on topographic maps of the study area. The mapped anomalies were used to direct observations on the ground to confirm discharge locations and types of inflow. The variations in grayscale patterns on the images were thus confirmed as representing shallow groundwater-discharge zones (seeps), outfalls of treated wastewater, or ditches draining runoff from impervious surfaces.
\end{abstract}

\section{Introduction}

Groundwater discharge from shallow aquifers to surface waters represents a substantial environmental component of the flow in most rivers and streams, accounting for as much as 50 percent of average annual streamflow (Winter and others, 1998). Additionally, this discharge is important for maintaining stream base flow and temperature stability during summer dry periods, thereby sustaining critical habitat for native flora and fauna (Winter and others, 1998; Torgersen and others, 1999; Hayashi and Rosenberry, 2002).

Groundwater discharge to streams and rivers varies broadly over spatial and temporal scales as a function of geologic and hydrologic setting (Sear and others, 1999). Discharge can occur as diffuse

\footnotetext{
${ }^{1}$ U.S. Geological Survey.

${ }^{2}$ Houlton Band of Maliseet Indians, Natural Resources Staff, Maine.
} 
(nonpoint-source) flow or focused (point-source) flow depending on variables such as bedrock and sediment morphology, hydraulic conductivity of the sediment layers and plant communities, streambed topography and permeability, hydraulic gradients driven by precipitation and snowmelt, and stream stage (Fan and others, 2007; Winter and others, 1998; Alley and others, 2002; Harvey and Bencala, 1993; Rosenberry and others, 2000; Conant, 2004; Sear and others, 1999). Groundwater discharge may also be a significant vector for urban- and agricultural-contaminant inputs to surface-water systems (Focazio and others, 1998; Fryar and others, 2000). Contaminant loads delivered to surface waters through groundwater pathways can be a substantial proportion of the total annual load (Taniguchi and others, 1997; Focazio and others, 1998). In a study of the Chesapeake Bay watershed, groundwater nitrate load contributed about half of the total annual nitrogen load to streams in the watershed (Bachman and others, 1998). In addition to geologic setting, the nature and magnitude of these contaminant loads are affected by land use and daily-to-seasonal fluctuations in the hydrologic regime within a particular watershed (Hayashi and Rosenberry, 2002; Fryar and others, 2000; Wroblicky and others, 1998).

Conventional methods that use instream data recordings of temperature and specific conductance to detect the source of groundwater provide information that is temporally continuous but constrained to reaches generally less than a kilometer long, with many potential discharge zones remaining undetected (Lowry and others, 2007; Torgersen and others, 2001). Other methods for characterizing groundwater discharge to surface waters have been employed, including seepage-meter measurements (Lee, 1977; Murdoch and Kelly, 2003; Paulsen and others, 2001; Rosenberry and Morin, 2004), piezometric measurements (Lee and Cherry, 1979; Winter and others, 1988; Kelly and Murdoch, 2003), temperature surveys (Lowry and others, 2007; Anderson, 2005; Conant, 2004; Constanz and Stonestrom, 2003; Constanz, 1998), studies with dyes and conservative tracers (Flury and Wai, 2003; Harvey and Bencala, 1993; Lee and others, 1980), and the assessment and modeling of hydrogeochemical data (Fryar and others, 2000; Harvey and Wagner, 2000; Harbaugh, 2005).

Thermal infrared (TIR) remote sensing has been used to measure surface-water temperatures and circulation patterns in larger water bodies such as lakes (Anderson and others, 1995; Kay and others, 2005), measure sea-surface temperatures (Donlon and others, 2002), assess reach- and watershed-scale stream-temperature patterns (Atwell and others, 1971; Faux and others, 2001; Kay and others, 2001; Torgersen and others, 2001), identify important habitat-sustaining thermal refugia for fish in streams (Belknap and Naiman, 1998; Torgersen and others, 1999), and identify zones of groundwater discharge into rivers, streams and estuaries (Banks and others, 1996; Urish and Gomez, 2004; Loheide and Gorelick, 2006). Aerial TIR remote sensing has been used successfully in studies in the northeastern U.S. and elsewhere to identify zones of groundwater discharge into surface waters (Roseen and others, 2002; Ballestero and Roseen, 2003; Urish and Gomez, 2004; Mulligan and Charette, 2006; Loheide and Gorelick, 2006; Banks and others, 1996; Torgersen and others, 2001; Raabe and Bialkowska-Jelinska, 2010).

Aerial TIR remote-sensing technology is particularly useful in that it provides a spatial context for evaluating relationships between land use and water quality in a watershed (Torgersen and others, 2001). Surface temperatures over long river reaches are easily surveyed at high resolution, and single images can be related to large areas of a water body. TIR sensors are capable of resolving temperature anomalies as small as $0.08{ }^{\circ} \mathrm{C}$ at resolutions of less than 1 meter $(\mathrm{m})$ in surface waters; however, they cannot penetrate the water column below the upper 0.1 millimeter $(\mathrm{mm})$ of the water surface (Torgersen and others, 2001; Kay and others, 2005). The detection of thermal anomalies in a water body is possible because of surficial thermal-energy variations caused by disruptions in the normal (in-situ) thermal flow in the stream. TIR imaging of potential groundwater-discharge zones relies on groundwater 
temperatures, which are thermally stable compared to seasonally variable surface-water temperatures (Banks and others, 1996). TIR imagery is typically displayed as grayscale with shades of gray representing differences in surface temperature. Generally, lighter shades of gray in IR images indicate warmer water, and darker gray cooler water (Banks and others, 1996; Torgersen and others, 2001; Whited and others, 2002).

Although point and nonpoint sources of urban and agricultural runoff likely contribute to waterquality impairment, the role of groundwater in delivering these contaminants to the Meduxnekeag River is not well understood. In December 2003 and November 2004, the U.S. Geological Survey (USGS), in cooperation with the Natural Resources Department of the Houlton Band of Maliseet Indians (HBMI), used aerial TIR videography as a means to identify and map spatial distributions of thermal anomalies along a 25-mile (mi) reach of the mainstem and tributaries of the Meduxnekeag River, near Houlton, Maine (fig. 1). Thermal anomalies were characterized and ranked on the basis of grayscale tonal intensities on the TIR images and the locations of the anomalies relative to the main-stem of the river. Aerially imaged thermal anomalies that were evaluated as being potentially significant discharges to the river were confirmed by ground verification; however, this verification did not include in situ measurements of water-surface temperatures.

\section{Purpose and Scope}

This report presents information on the use of aerial TIR sensing to identify potential groundwater and other thermal discharge zones on a 25-mi reach of the Meduxnekeag River near Houlton, Maine. The report evaluates the viability of the use of TIR remote sensing as a technique to identify and map potential groundwater seeps and other inflows, such as flows from natural springs, storm drains, or discharge pipes associated with urban activities along the Meduxnekeag River; characterizes the potential importance of discharges to the river identified by aerially imaged thermal anomalies; and describes the process of ground confirmation of thermal anomalies identified on TIR imagery as those of potential importance.

\section{Previous Investigations}

The Houlton Band of Maliseet Indians, Department of Natural Resources, has actively monitored the water quality of the river and its tributaries for more than two decades, observed seasonal episodic blooms of nuisance filamentous algae, and documented elevated concentrations of fecalcoliform bacteria and inorganic nutrients as well as low dissolved oxygen concentrations (unpublished data on file with the HBMI).

Several organizations have previously documented water-quality problems in the Meduxnekeag River. The Maine Department of Environmental Protection (DEP) sampled for total phosphorus and other indicators of stream water-quality and identified point sources that could be contributing to impairment of the river (Maine Department of Environmental Protection, 2000). Independent investigators found that algal mats covered as much as 90 percent of the streambed during the summer at the sites they monitored (William Ball, Acheron Engineering, Environmental and Geologic Consultants, written commun., 2001). Fish-consumption advisories have been issued for the Meduxnekeag River because of elevated levels above Maine DEP standards of the pesticide dichlorodiphenyl-trichloroethane (DDT) in fish tissue (Maine Department of Environmental Protection, 2002) and for all Maine rivers because of elevated levels of mercury in fish tissue (Maine Department of Environmental Protection, 1998b). The river's water quality is affected by sediments and pesticides in agricultural runoff, stormwater runoff and sewer overflow from urban commercial and residential areas, 
inflows from rural residential septic systems, and wastewater and thermal effects from industrial areas. Schalk and Tornes (2005) suggested that sediment, nutrients, and organic compounds from agricultural, urban, and industrial areas are likely mobilized during high seasonal periods of runoff.

\section{Description of Study Area}

The Meduxnekeag River in southeastern Aroostook County in northern Maine drains 516 square miles (mi ${ }^{2}$ (fig. 1) at its confluence with the St. John River in New Brunswick, Canada. The river begins at Meduxnekeag Lake, $8 \mathrm{mi}$ west of the town of Houlton, Maine. The South Branch joins the Meduxnekeag River near Houlton where the river turns north-northeast, flowing for approximately $10 \mathrm{mi}$ before it crosses the Canadian border to its confluence with the St. John River. Near Houlton, Maine, at the most downstream point where streamflow is measured by the USGS (station ID 01018035), the drainage area is $257 \mathrm{mi}^{2}$ (fig. 2). Upstream from the Canadian border, the Meduxnekeag River has a drainage area of $289 \mathrm{mi}^{2}$ (Fontaine and others, 1982). The watershed includes $67 \mathrm{mi}$ of the main-stem river and $290 \mathrm{mi}$ of tributaries. Many small lakes in the upstream parts of the watershed are at a higher elevation than the agricultural lands in the lower part of the watershed.

Northeastern Maine is characterized by cold winters and short, warm summers. The growing season is 100 to 125 days. Average annual precipitation is about 39 inches (in.), which includes the water equivalent of $95 \mathrm{in}$. of snow. Average temperatures range from $12^{\circ} \mathrm{F}$ in January to $68^{\circ} \mathrm{F}$ in July (National Oceanic and Atmospheric Administration, 2002). Although precipitation is distributed fairly evenly throughout the year, most of the annual streamflow occurs during the spring snowmelt period and before evapotranspiration increases following leafout. Snowmelt runoff has been observed to cause severe erosion in late winter and early spring (Southern Aroostook County Soil and Water Conservation District, 1993). Occasional large summer and fall storms can also result in substantial amounts of runoff.

The USGS maintains three streamflow gages (or streamgages) in the study area (fig. 2). Streamgage 01017960, the most upstream streamgage, was established in 2003 in cooperation with the Maine DEP, Town of Houlton, and Tate and Lyle Manufacturing above the confluence of the main stem of the Meduxnekeag River and the South Branch. This streamgage is about 2 mi upstream from the town of Houlton, and the watersheds of its major tributaries Mill Stream and Mill Brook are primarily forested (figs. 1, 3). Long-term streamflow statistics for this streamgage were not calculated for this upstream site because of the short period of record.

Station 01018000, Meduxnekeag River near Houlton, was active from 1940 to 1982. During this time period, rating curves were established, and periodic measurements of water temperature, specific conductance, and streamflow were made. Station 01018000 was reactivated in 2003, in cooperation with HBMI, for additional streamflow measurements and water-quality monitoring. Of 56 measurements of streamflow on record for station 01018000, 35 were made during the spring months March to May; the median for these measurements was 1,760 cubic feet per second $\left(\mathrm{ft}^{3} / \mathrm{s}\right)$. Median measured streamflow during the rest of the year was $101 \mathrm{ft}^{3} / \mathrm{s}$. The peak recorded flow at station $01018000 \mathrm{was} 6,010 \mathrm{ft}^{3} / \mathrm{s}$ on April 4, 1976, probably in response to snowmelt runoff. Station 01018035, Meduxnekeag River at Lowery Road near Houlton, Maine, the most downstream main-stem station on the Meduxnekeag River, was established in July 2005, in cooperation with HBMI, for additional streamflow measurements and water-quality monitoring.

One town (Houlton, population 5,270 in 2000) and one industry, a manufacturing plant, have permitted outfalls to the Meduxnekeag River (Maine Department of Environmental Protection, 1998a, 2003). Houlton's municipal wastewater outfall is just downstream from the town limits. The manufacturing plant, which processes food starch (Town of Houlton, 2004), is just downstream from 
station 01017960 and upstream from the confluence of the South Branch with the main stem of the Meduxnekeag River. Most irrigation of agricultural fields is by withdrawals from the Meduxnekeag River (Matthew Williams, University of Maine Extension, written commun., 2004). The demand for irrigation water, however, puts stress on aquatic habitat during low-flow periods (Aroostook Water and Soil Management Board, 1996).

Land cover in the Meduxnekeag River watershed is primarily forest with smaller amounts of agriculture (fig. 3). Forests cover about 79 percent of the watershed; agricultural lands, about 17 percent; and urban areas and open water, about 4 percent (Southern Aroostook County Soil and Water Conservation District, 1993). In 1993, agricultural lands included approximately 23,900 acres of active cropland, 3,900 acres of hay and pasture, and 3,000 acres of grassland. Some 393 farms of all sizes with 2,443 separate fields occupy 30,800 acres of agricultural land. About 20,000 acres of potatoes, most commonly in rotation with grain, are grown on 212 farms. Fifty-two livestock operations support 2,350 animals, mostly dairy or beef cattle. Most of the agricultural land is concentrated in the lower half of the watershed in and downstream of the Houlton area. The general trend in land use is toward gradual increases in urban and suburban areas at the expense of agricultural and forested land (Southern Aroostook County Soil and Water Conservation District, 1993).

The thickness of unconsolidated deposits in the Meduxnekeag River watershed is variable. In general, the overburden is calcareous till derived from weathered bedrock (Thompson and Borns, 1985). Much of the soil is classified as highly erodible or potentially highly erodible (Arno, 1964; U.S. Department of Agriculture, 1994). Most of the arable soils are in agricultural production, and the steep, stony, and poorly drained soils are in forests (Arno, 1964). Land surface is rolling, with hills reaching an elevation of 200 to 500 feet (ft) above valley floors (fig. 4).

\section{Aerial and Ground-Based Methods of Data Collection}

Aerial TIR images for this study were collected from a single-engine, fixed-wing aircraft on December 3-4, 2003, and November 26, 2004. With the images obtained during the two flights, surfacewater thermal anomalies were interpreted as shallow groundwater-discharge zones (seeps), outfalls of treated wastewater, or ditches draining runoff from impervious surfaces.

\section{TIR Remote Sensing of Surface-Water Temperature Anomalies}

Groundwater discharge zones (seeps), natural springs, and surface drains in the study area were identified as thermal anomalies by using aerial TIR remote sensing (provided by Davis Aviation, Kent, Ohio). Thermal anomalies were assessed on two separate occasions: December 3-4, 2003, between 23:45 and 04:30 Eastern Standard Time (EST); and November 26, 2004, between 19:14 and 23:02 EST. These dates were chosen to target seasonal low-flow periods and low infrared and visual interferences caused by tree foliage and to capture maximum temperature gradients between groundwater and other inputs relative to the in situ surface-water temperature of the river. Because the surveillance was done when stream temperatures were close to freezing, shallow groundwater-seepage zones or inputs from other sources such as natural springs, pipes, drains, and septic systems associated with thermal anomalies were expected to be warmer than the receiving river water.

\section{Aerial TIR Data Collection}

TIR images were made by a Mitsubishi IR-M600 Thermal Imaging Camera (Mitsubishi, Tokyo, Japan) equipped with a platinum silicide Schottky-Barrier infrared detector and a polarized infrared $50-\mathrm{mm} \mathrm{f} / 1.2$ lens. The detectable thermal-radiation wavelength band for the detector was $3-5 \mu \mathrm{m}$. The 
resolution of the camera was 512 by 512 pixels, and it provided a sensitivity of $0.08{ }^{\circ} \mathrm{C}$ and a field recording speed of 60 frames per second. The angular field of view of the detector equipped with the $50-\mathrm{mm}$ lens was $14^{\circ}$ (horizontal) by $11^{\circ}$ (vertical). From an altitude of $500 \mathrm{~m}$, the field of view on the ground equated to approximately $135 \mathrm{~m}$ (horizontal) by $105 \mathrm{~m}$ (vertical). The TIR camera was mounted in a single-engine fixed-wing aircraft above an opening in the floor of the fuselage, enabling a straightdown orientation. Imaging altitudes ranged from 500 to $800 \mathrm{~m}$ above ground surface. Flight paths for both aerial assessments began at Meduxnekeag Lake, headwater for the Meduxnekeag River, and continued approximately 25 river miles downstream through the town of Houlton to the Canadian border. Aerial surveillance also covered tributaries near their confluence with the river's main stem, as well as sections of the South Branch from Cary to Carys Mill and the North Branch from the Canadian border to approximately the river's confluence with Meadow Brook.

\section{Mapping and Image Processing}

Real-time infrared images were displayed to the pilot on a video monitor and simultaneously recorded by a Sony DCR-TRV900 digital video recorder (Sony, Tokyo, Japan). The video output of the thermal imager (RS170, $75 \mathrm{ohms}$ ) was routed through a video encoder-decoder (VED) that labeled the video with a continuous stream of global positioning system (GPS)-derived information, including date, time, latitude, longitude, altitude, and air speed. GPS locations were obtained each second and used to georeference frames on the video tape. A bar code containing the same alphanumeric GPS information appeared on the left side of the infrared images and was used by the VED during video playback and analysis. The aerial infrared digital-imaging analysis (AIDIA) included the use of 8.5-by-11-inch map sheets from DeLorme's MapExpert 2.0, annotated USGS 7.5-minute topographic maps, original MiniDV digital videotape of infrared imagery, and CD-ROMs with images of the thermal anomalies identified during each of the flights. Although aerial TIR imaging can provide accurate measurements of surface-water temperatures, actual surface-water temperature data were not acquired for this study. Instead, identified thermal anomalies were mapped by using tonal differences in grayscale on the digital IR video images. Because of the seasonal timing of the flight, surface-water temperatures were assumed to be lower than the groundwater temperatures. The thermal anomalies appear as areas of brighter contrast on the image.

\section{Characterization and Ground Verification of Aerially Identified Thermal Anomalies}

Surface-water temperatures of the Meduxnekeag River vary seasonally and are very cold $\left(4-6{ }^{\circ} \mathrm{C}\right)$ during late fall and early winter compared to warmer, more thermally stable $\left(10-12{ }^{\circ} \mathrm{C}\right)$ groundwater. Warmer water discharges appear as points that are lighter or brighter on the TIR images than the darker (colder) receiving river water. Images were evaluated on the basis of grayscale tonal contrast of the thermal anomaly; higher contrast was generally interpreted as representing a greater temperature difference between the discharge and the receiving river water. On the basis of a qualitative assessment of grayscale contrast, thermal anomalies identified in the TIR images were assigned a preliminary characterization as groundwater seeps, discharges from surface drains or pipes, or another type of warm water input (tables 1 and 2). Thermal anomalies were then prioritized for ground verification on the basis of the intensity of grayscale contrast (a function of temperature, volume, and velocity of discharge), preliminary characterization, and proximity to the Meduxnekeag River. Following image analysis, characterization, and prioritization, the georeferenced infrared images of the thermal anomalies were compared to features on topographic maps of the study area to direct observations on the ground to confirm discharge location and type. 


\section{Identification of Thermal Anomalies}

Eleven thermal anomalies were identified on the basis of data from the December 2003 flight (fig. 5, table 1), and 17 were identified on the basis of data from the November 2004 flight (fig. 5 (some not shown to allow larger map scale), table 2). Temperature anomalies were caused by the discharge of groundwater (including shallow groundwater) or surface water from drains, ditches, or wastewater outfalls into colder river water. The types of anomalies identified in this study included groundwater seeps, outfalls from surface drains or ditches originating from buildings, and permitted discharge from outfall of the Houlton wastewater-treatment plant. Groundwater seeps were identified on the banks of small tributary streams, the Meduxnekeag River mainstem, near Nickerson Lake adjacent to the river, in streambeds and flood plains adjacent to the river, and on a hillside. TIR images of most of the identified thermal anomalies are shown on figures 6A and B. The seeps appear as bright areas against backgrounds in various shades of gray. Thermal anomaly no. 17 observed during the November 2004 flight was identified as a seep originating near a farm and possibly connected to the Meduxnekeag River (figs. 5 and 6B, table 2). The wide variation in the shape, size, and intensity (brightness contrast) of the temperature anomalies may indicate a range of different seep or surface-drain discharge rates and different rates of mixing with surface water.

\section{Summary}

Aerial thermal infrared remote-sensing surveys were conducted by the U.S. Geological Survey, in cooperation with the Natural Resources Department of the Houlton Band of Maliseet Indians, during aircraft flights over a 25-mile reach of the mainstem of the Meduxnekeag River near Houlton, Maine, on December 3-4, 2003, and November 26, 2004. Eleven thermal anomalies were identified on the basis of data from the December 2003 flight, and 17 were identified on the basis of data from the November 2004 flight. Analyses of thermal infrared images indicated groundwater-discharge zones, as well as other types of thermal inputs, including outfalls from surface drains or ditches originating from buildings and permitted discharge from the outfall of the Houlton Wastewater Treatment Plant. All of the thermal anomalies were found to be contributing sources of inflow. The use of aerial thermal infrared remote-sensing was instrumental in locating these seeps.

\section{References Cited}

Alley, W.M., Healy, R.W., LaBaugh, J.W., and Reilly, T.E., 2002, Flow and storage in groundwater systems: Science, v. 296, no. 5575, p. 1985-1990.

Anderson, J.M., Duck, R.W., and McManus, J., 1995, Thermal radiometry-A rapid means of determining surface water temperature variations in lakes and reservoirs: Journal of Hydrology, v. 173, p. 131-144.

Anderson, M.P., 2005, Heat as a ground water tracer: Ground Water, v. 43, no. 6, p. 951-968.

Arno, J.R., 1964, Soil survey of Aroostook County, southern part: Washington, D.C., Soil Conservation Service (now Natural Resources Conservation Service), U.S. Department of Agriculture, Series 1961, no. 6, 62 p. with 123 map plates, accessed September 9, 2008, at ftp://ftpfc.sc.egov.usda.gov/ME/soilsurveys/saroostook.pdf.

Aroostook Water and Soil Management Board, 1996, How to deal with low flow periods and irrigating farmer's and environmental concerns in Aroostook County: Presque Isle, Maine, Aroostook Water and Soil Management Program, 8 p. 
Atwell, B.H., McDonald, R.B., and Bartolucci, L.A., 1971, Thermal mapping of streams from airborne radiometric scanning: Water Resources Bulletin, v. 7, p. 228-243.

Bachman, L.J., Lindsey, B.D., Brakebill, J.W., and Powars, D.S., 1998, Ground-water discharge and base-flow nitrate loads of nontidal streams, and their relation to a hydrogeomorphic classification of the Chesapeake Bay watershed, middle Atlantic coast: U.S. Geological Survey Water-Resources Investigations Report 98-4059, $71 \mathrm{p}$.

Ballestero, T.P., and Roseen, Robert, 2003, Characterization of groundwater discharge to Hampton Harbor: New Hampshire Estuaries Project, Final Report, August 26, 2003, 17 p.

Banks, W.S.L., Paylor, R.L., and Hughes, W.B., 1996, Using thermal-infrared imagery to delineate ground-water discharge: Ground Water, v. 34, no. 3, p. 434-443.

Belknap, W., and Naiman, R.J., 1998, A GIS and TIR procedure to detect and map wall-base channels in western Washington: Journal of Environmental Management, v. 52, p. 147-160.

Conant, B., Jr., 2004, Delineating and quantifying ground water discharge zones using streambed temperatures: Ground Water, v. 42, p. 243-257.

Constanz, J.E., 1998, Interaction between stream temperature, streamflow, and groundwater exchanges in alpine streams: Water Resources Research, v. 34, p. 1609-1615.

Constantz, J.E., and Stonestrom, D.A., 2003, Heat as a tracer of water movement near streams, in Stonestrom, D.A., and Constantz, J., eds., Heat as a tool for studying the movement of ground water near streams: U.S. Geological Survey Circular 1260, p. 1-6.

Donlon, C.J., Minnett, P.J., Gentemann, Chelle, Nightingale, T.J., Barton, I.J., Ward, B., and Murray, M.J., 2002, Toward improved validation of satellite sea surface skin temperature measurements for climate research: Journal of Climate, v. 15, no. 4, p. 353-369.

Fan, Y., Toran, L., and Schlische, R.W., 2007, Groundwater flow and groundwater-stream interaction in fractured and dipping sedimentary rocks-Insights from numerical models: Water Resources Research, v. 43, W01409, doi:10.1029/2006WR004864.

Faux, R.N., Lachowski, H., Maus, P., Torgersen, C.E., and Boyd, M.S., 2001, New approaches for monitoring stream temperature-Airborne thermal infrared remote sensing: U.S. Department of Agriculture, Forest Service Engineering Remote Sensing Applications Center, 29 p.

Flury, Markus, and Wai, N.N., 2003, Dyes as tracers for vadose zone hydrology: Reviews of Geophysics, v. 41, no. 1002, doi:10.1029/2001RG000109, accessed August 8, 2012, at http://www.agu.org/pubs/crossref/2003/2001RG000109.shtml.

Focazio, M.J., Plummer, L.N., Böhlke, J.K., Busenberg, E., Bachman, L.J., and Powars, D.S., 1998, Preliminary estimates of residence times and apparent ages of groundwater in the Chesapeake Bay Watershed, and water-quality data from a survey of springs: U.S. Geological Survey Water-Resources Investigations Report 97-4225, 75 p.

Fontaine, R.A., Herrick, E., and Norman, N., 1982, Drainage areas of surface water bodies of the St. John River basin in northern Maine: U.S. Geological Survey Open-File Report 78-556G, 70 p. Fryar, A.E., Wallin, E.J., and Brown, D.L., 2000, Spatial and temporal variability in seepage between a contaminated aquifer and tributaries to the Ohio River: Groundwater Monitoring and Remediation, v. 20, p. 129-146.

Harbaugh, A.W., 2005, MODFLOW-2005, the U.S. Geological Survey modular ground-water modelThe ground-water flow process: U.S. Geological Survey Techniques and Methods, book 6, chap. A16, variously paged.

Harvey, J.W., and Bencala, K.E., 1993, The effect of streambed topography on surface-subsurface water exchange in mountain catchments: Water Resources Research, v. 29, p. 89-98. 
Harvey, J.W., and Wagner, B.J., 2000, Quantifying hydrologic interactions between streams and their subsurface hyporheic zones, in Jones, J.B., and Mulholland, P.J., eds., Streams and Ground Waters: San Diego, Calif., Academic Press, p. 3-44.

Hayashi, M., and Rosenberry, D.O., 2002, Effects of groundwater exchange on the hydrology and ecology of surface water: Ground Water, v. 40, no. 3, p. 309-316.

Kay, J., Handcock, R.N., Gillespie, A., Konrad, C., Burges, S., Naveh, N., and Booth, D., 2001, Streamtemperature estimation from thermal infrared images: International Geosciences and Remote Sensing Symposium, v. 1, p. 112-114.

Kay, J.E., Kampf, S.K., Handcock, R.N., Cherkauer, K.A., Gillespie, A.R., and Burges, S.J., 2005, Accuracy of lake and stream temperatures estimated from thermal infrared images: Journal of the American Water Resources Association, v. 41, no. 5, p. 1161-1175.

Kelly, S.E., and Murdoch, L.C., 2003, Well tests for determining the hydraulic conductivity of a stream bed: Ground Water, v. 41, no. 4, p. 431-439.

Lee, D.R., 1977, A device for measuring seepage flux in lakes and estuaries: Limnology and Oceanography, v. 22, p. 140-147.

Lee, D.R, and Cherry, J.A., 1979, A field exercise on groundwater flow using seepage meters and minipiezometers: Journal of Geological Education, v. 27, p. 6-10.

Lee, D.R., Cherry, J.A., and Pickens, J.F., 1980, Groundwater transport of a salt tracer through a sandy lakebed: Limnology and Oceanography, v. 25, no. 1, p. 45-61.

Loheide, S.P., II, and Gorelick, S.M., 2006, Quantifying stream-aquifer interactions through analysis of remotely sensed thermographic profiles and in-situ temperature histories: Environmental Science and Technology, v. 40, no. 10, p. 3336-3341.

Lowry, C.S., Walker, J.F., Hunt, R.J., and Anderson, M.P., 2007, Identifying spatial variability of groundwater discharge in a wetland using a distributed temperature sensor: Water Resources Research, v. 43, W10408, doi:10.1029/2007WR006145.

Maine Department of Environmental Protection, 1998a, Maine Section 303(d) waters-1998: Maine Department of Environmental Protection, accessed February 5, 2004, at http://www.state.me.gov/dep/blwq/docmonitoring/303d981.pdf.

Maine Department of Environmental Protection, 1998b, State of Maine unified watershed assessment: Maine Department of Environmental Protection, accessed March 8, 2004, at http:/www.maine.gov/dep/blwq/docwater-shed/uwacate2.pdf.

Maine Department of Environmental Protection, 2000, Meduxnekeag River TMDL (Final): Maine Department of Environmental Protection, Division of Environmental Assessment, DEPLW2000-22, $13 \mathrm{p}$.

Maine Department of Environmental Protection, 2002, Integrated water quality and monitoring assessment report: Maine Department of Environmental Protection, accessed March 8, 2004, at http://www.maine.gov/dep/blwq/2002Appendix.pdf.

Maine Department of Environmental Protection, 2003, Status of licensed discharges: Maine Department of Environmental Protection, accessed February 5, 2004, at http://www.maine.gov/dep/blwq//report/statuslicenseddischarge03.pdf.

Mulligan, A.E., and Charette, M.A., 2006, Intercomparison of submarine groundwater discharge estimates from a sandy unconfined aquifer: Journal of Hydrology, v. 327, no. 3-4, p. 411-425. Murdoch, L.C., and Kelly, S.E., 2003, Factors affecting the performance of conventional seepage meters: Water Resources Research, v. 39, no. 6, 1163, doi:10.1029/2002WR001347. 
National Oceanic and Atmospheric Administration, 2002, Monthly station normals of temperature, precipitation, and heating and cooling degree days, 1971-2000, Maine: Asheville, N.C., National Climatic Data Center, Climatography of the United States, no. 81, 16 p.

National Oceanic and Atmospheric Administration, 2005, Climatological Data, New England: National Climatic Data Center, v. 117, no. 1-12, variously paginated.

Paulsen, R.J., Smith, C.F., O'Rourke, Daniel, and Wong, Teng-Fong, 2001, Development and evaluation of an ultrasonic ground water seepage meter: Ground Water, v. 39, no. 6, p. 904-911.

Raabe, E.A., and Bialkowska-Jelinska, E., 2010, Thermal imaging of the Waccasassa Bay PreserveImage acquisition and processing: U.S. Geological Survey Open-File Report 2010-1120, 61 p.

Roseen, R.M., Brannaka, L.K., and Ballestero, T.P., 2002, Nutrient loading from groundwater and its role in TMDLs, in Codrescu, A., ed., Total maximum daily load (TMDL) environmental regulations, Fort Worth, Tex.,, March 11-13, 2002, Proceedings: St. Joseph, Mich., American Society of Agricultural and Biological Engineers, p. 262-267.

Rosenberry, D.O., and Morin, R.H., 2004, Use of an electromagnetic seepage meter to investigate temporal variability in lake seepage: Ground Water, v. 42, no. 1, p. 68-77.

Rosenberry, D.O., Striegl, R.G., and Hudson, D.C., 2000, Plants as indicators of focused ground water discharge to a northern Minnesota lake: Ground Water, v. 38, p. 296-303.

Schalk, C.W., and Tornes, Lan, 2005, Nutrients, organic compounds, and mercury in the Meduxnekeag River watershed, Maine, 2003: U.S. Geological Survey Scientific Investigations Report 2005-5111, $31 \mathrm{p}$.

Sear, D.A., Armitage, P.D., and Dawson, F.H., 1999, Groundwater dominated rivers: Hydrological Processes, v. 13, p. 255-276.

Southern Aroostook County Soil and Water Conservation District, 1993, Watershed protection plan, environmental assessment, main branch Meduxnekeag River watershed, Aroostook County, Maine: Southern Aroostook County Soil and Water Conservation District, Houlton Band of Maliseet Indians, Houlton, Maine, 86 p.

Taniguchi, M., Sharma, M.L., Herne, D., and Byrne, J., 1997, Assessing groundwater nutrient discharge into Lennard Brook, Western Australia: Freshwater Contamination, no. 243, p. 195-201.

Thompson, W.B., and Borns, H.W., Jr., eds., 1985, Surficial geologic map of Maine: Maine Geological Survey, Department of Conservation, 1 pl., scale 1:500,000.

Torgersen, C.E., Faux, R.N., McIntosh, B.A., Poage, N.J., and Norton, D.J., 2001, Airborne thermal remote sensing for water temperature assessment in rivers and streams: Remote Sensing of the Environment, v. 76, no. 3, p. 386-398.

Torgersen C.E., Price, D.M., Li, H.W., and McIntosh, B.A., 1999, Multiscale thermal refugia and stream habitat associations of Chinook salmon in northeastern Oregon: Ecological Applications, v. 9, p. 301-319.

Town of Houlton, 2004, Regional economic development and strategic marketing plan: Houlton, Maine, Jim Damicis Associates, 93 p.

Urish, D.W., and Gomez, A.L., 2004, Groundwater discharge to Greenwich Bay, paper no. 3, in Schwartz, M., ed., Restoring water quality in Greenwich Bay-A whitepaper series: Rhode Island Sea Grant, Narragansett, R.I., 8 p.

U.S. Department of Agriculture, Natural Resources Conservation Services, 1994, State soil geographic (STATSGO) database, data use information: Lincoln, Nebraska, National Soil Survey Center Miscellaneous Publication 1492, 39 p., appendixes. 
Whited, D., Stanford, J.A., and Kimball, J.S., 2002, Application of airborne multispectral digital imagery to quantify riverine habitats at different base flows: River Research and Applications, v. 18, p. 583-594.

Winter, T.C., Harvey, J.W., Franke, O.L., and Alley, W.M., 1998, Ground water and surface water-A single resource: U.S. Geological Survey Circular 1139, 79 p. (Also available at http://pubs.usgs. gov/circ/circ1139/.)

Winter, T.C., LaBaugh, J.W., and Rosenberry, D.O., 1988, The design and use of a hydraulic potentiomanometer for direct measurement of differences in hydraulic head between groundwater and surface water: Limnology and Oceanography, v. 33, p. 1209-1214.

Wroblicky, G.J., Campana, M.E., Valett, H.M., and Dahm, C.N., 1998, Seasonal variation in surfacesubsurface water exchange and lateral hyporheic area of two stream-aquifer systems: Water Resources Research, v. 34, no. 3, p. 317-328. 


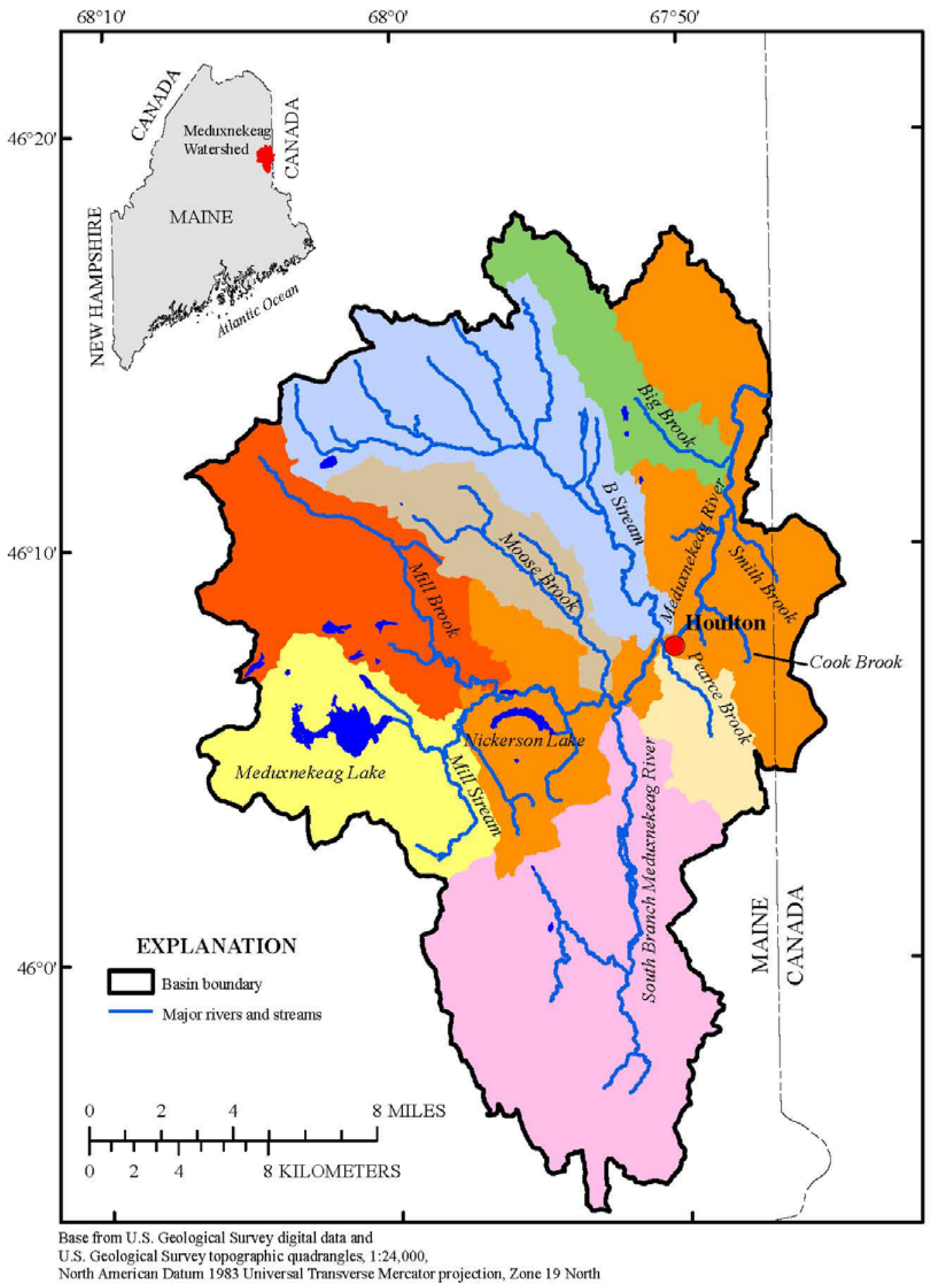

Figure 1. Map showing hydrography of the Meduxnekeag River watershed in northeastern Maine. Colors are used only to differentiate individual subbasins. 


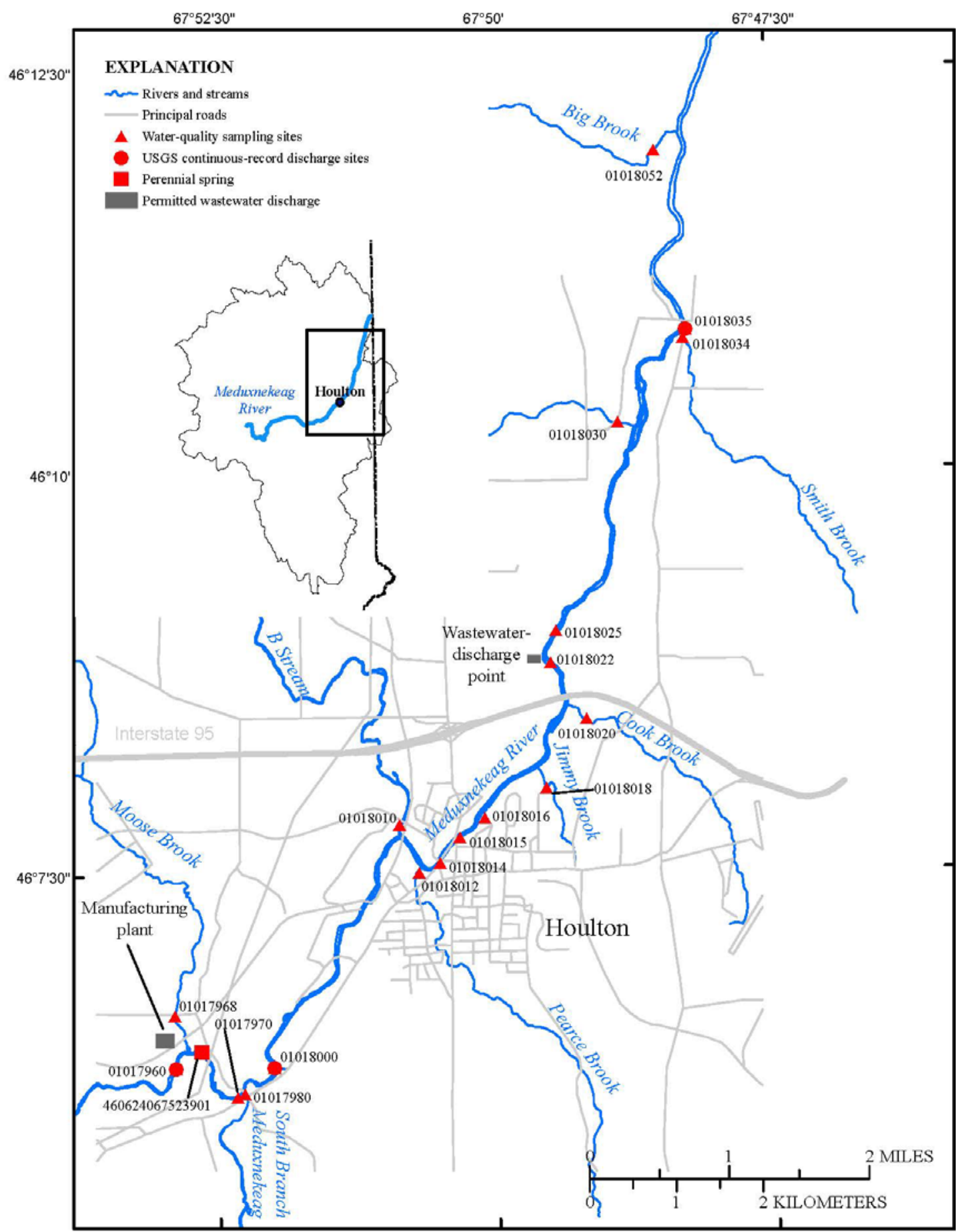

Base from U.S. Geological Survey digital data and

U.S. Geological Survey topographic quadrangles, 1:24,000,

North American Datum 1983 Universal Transverse Mercator projection, Zone 19 North

Figure 2. Map showing locations of USGS streamgages and sampling stations in the Meduxnekeag River watershed near Houlton in northeastern Maine. 


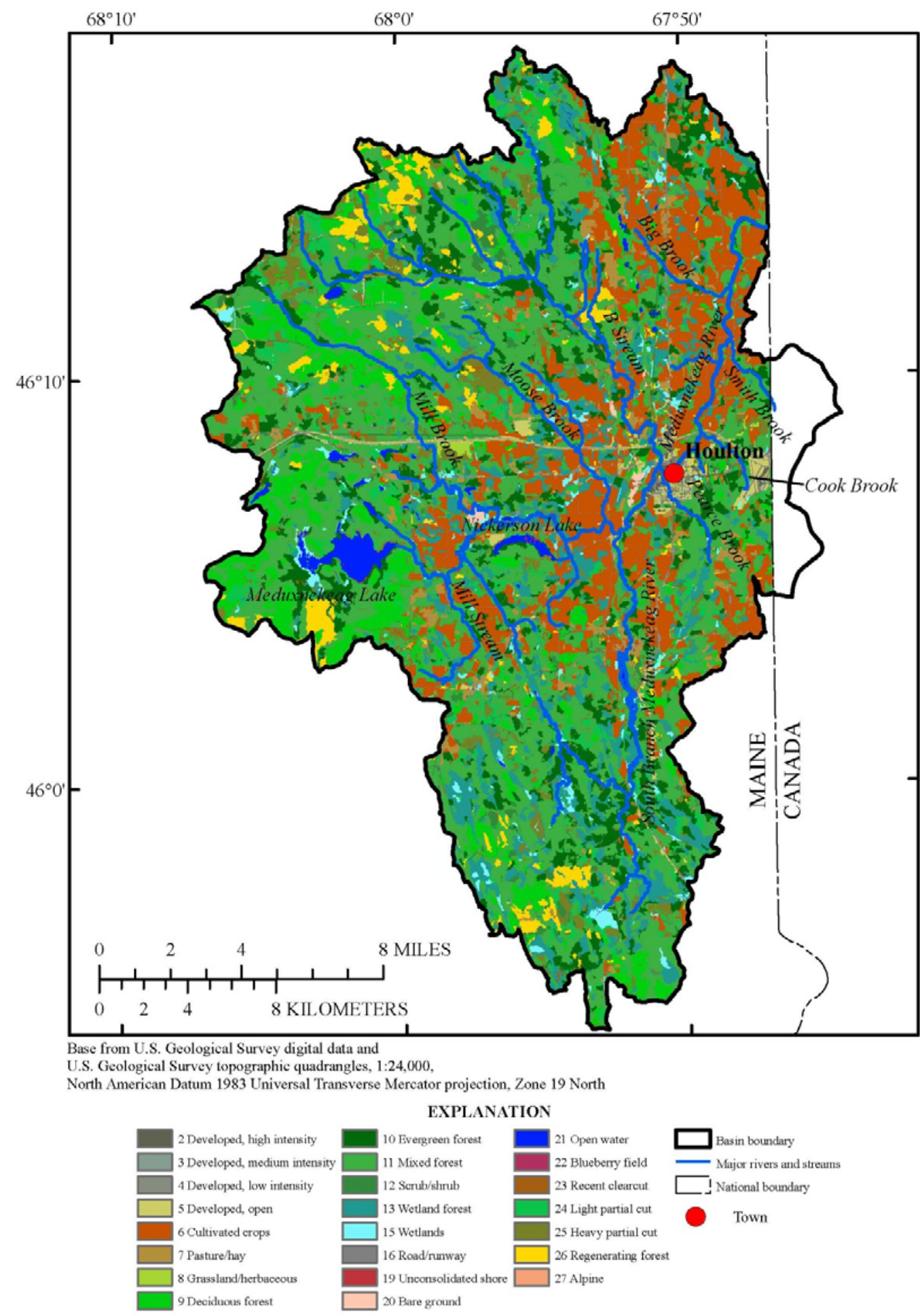

Figure 3. Map showing land use in the Meduxnekeag River watershed near Houlton in northeastern Maine. 


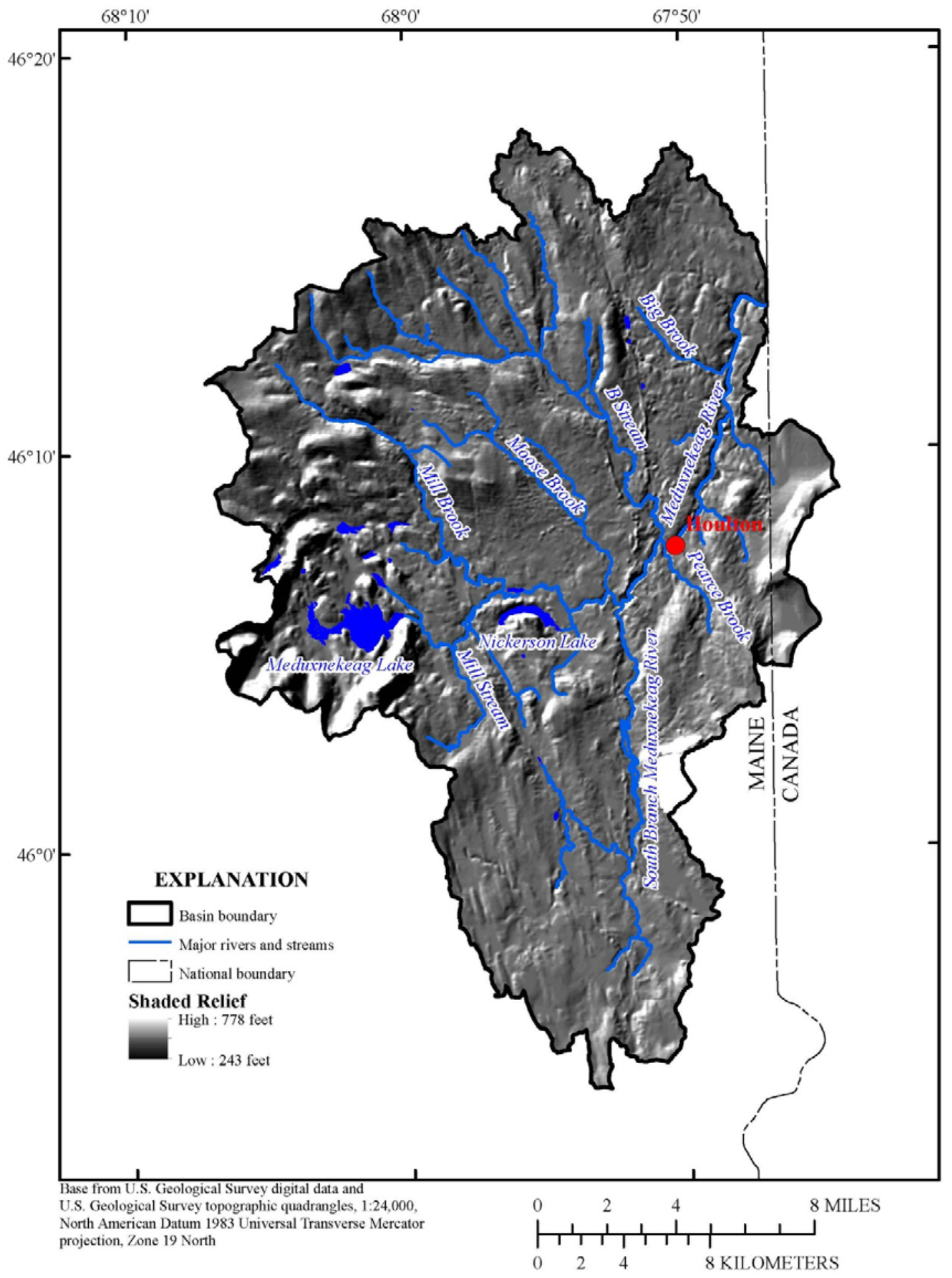

Figure 4. Map showing topography and hydrography of the Meduxnekeag River watershed near Houlton in northeastern Maine. 


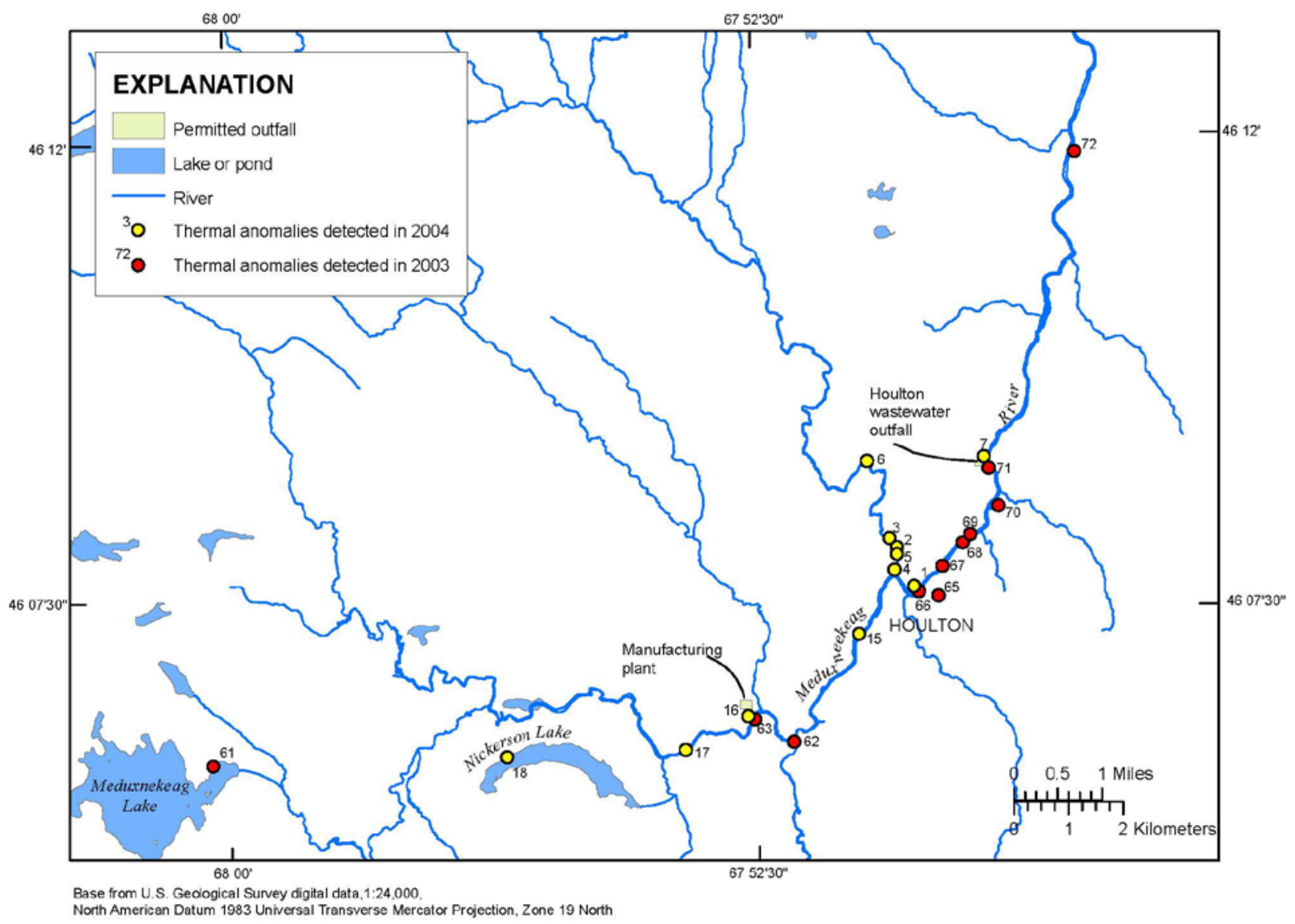

Figure 5. Map showing surveillance reaches along the Meduxnekeag River near Houlton, Maine, in the aerial thermal-imaging study on A, December 3-4, 2003, and B, November 26, 2004. 


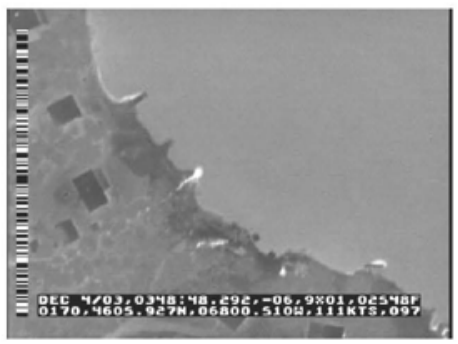

Number 61

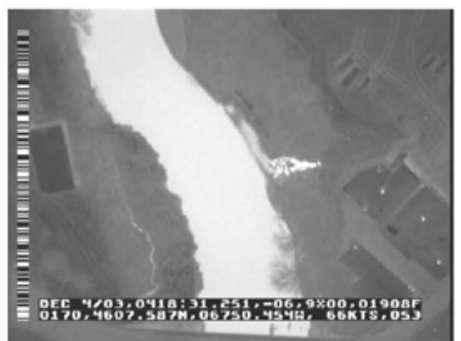

Number 65

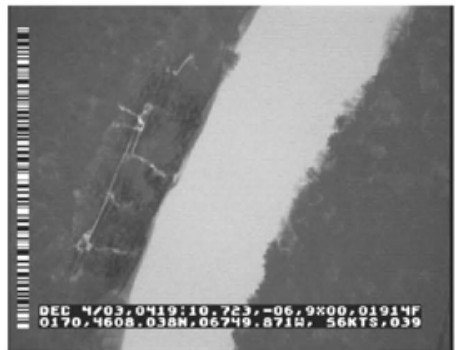

Number 68

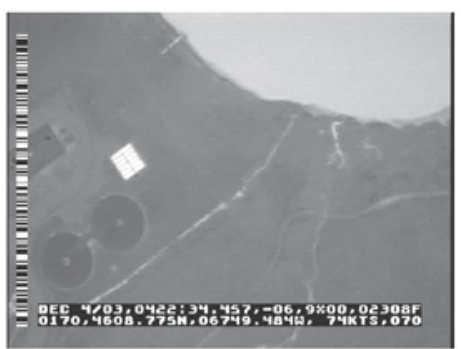

Number 71

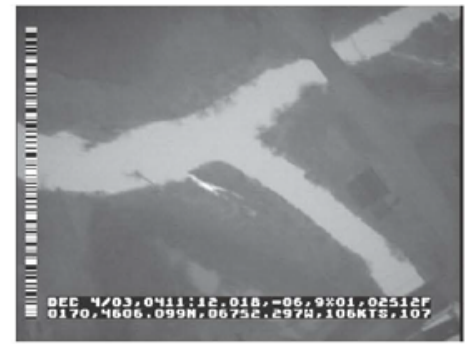

Number 62

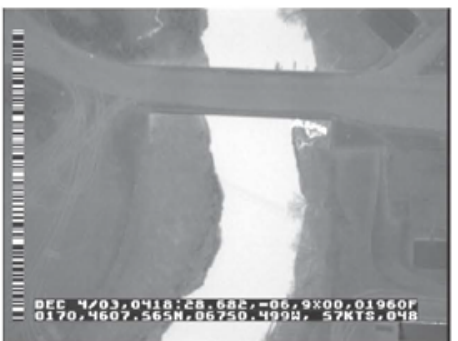

Number 66

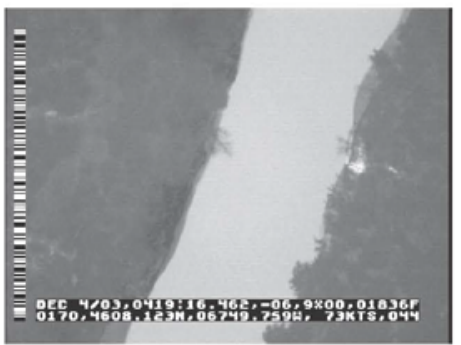

Number 69

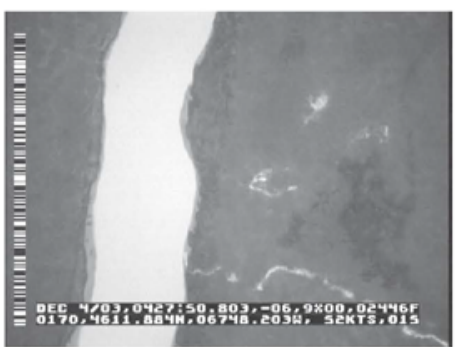

Number 72

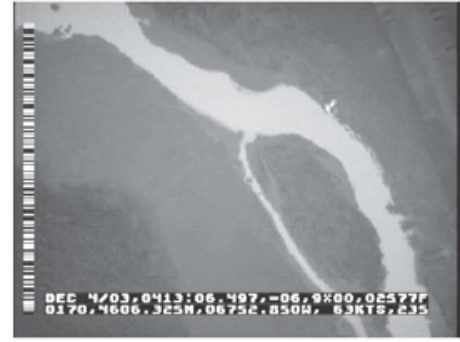

Number 63

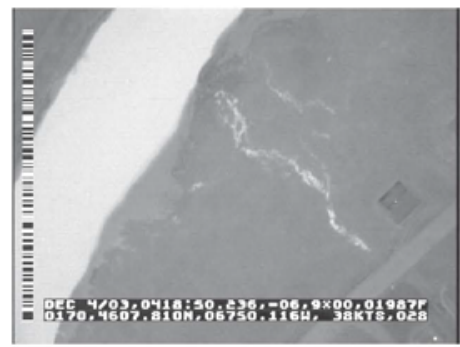

Number 67

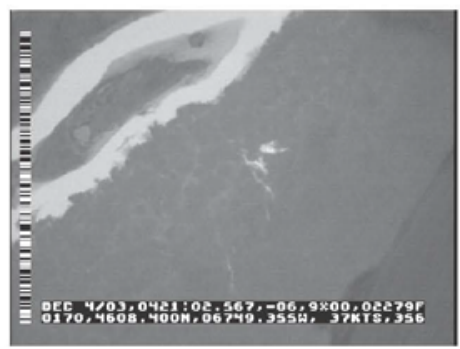

Number 70

Figure 6. Images of thermal anomalies for discharges into the Meduxnekeag River near Houlton, Maine, during the A, December 3-4, 2003, flight (images 61-72) and the B, November 26, 2004, flight (images 1-18). [Image numbers are anomalies described in tables 1 and 2.] 


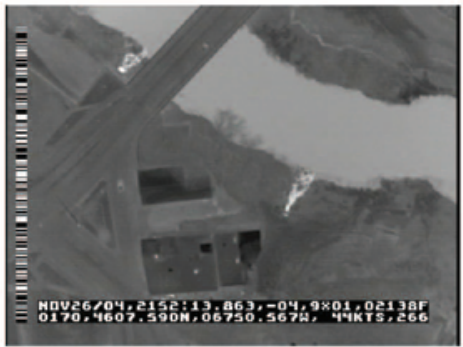

Number 1

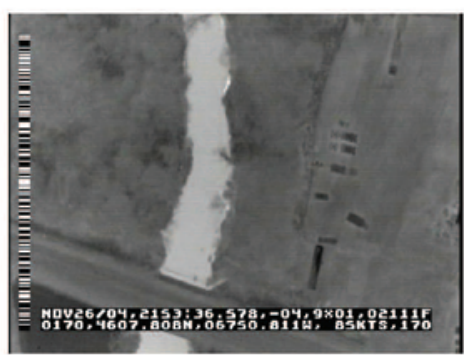

Number 4

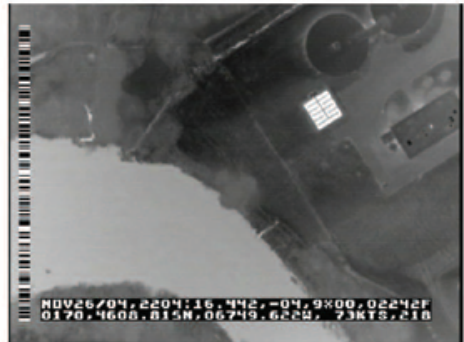

Number 7

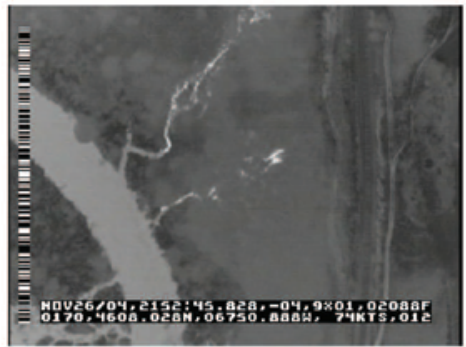

Number 2

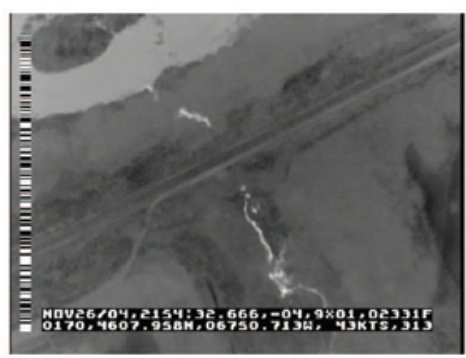

Number 5

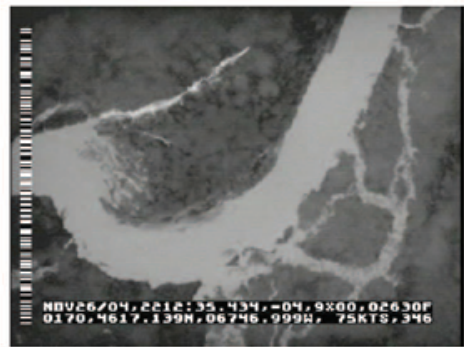

Number 8

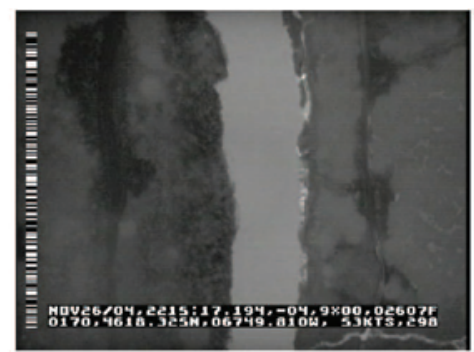

Number 11

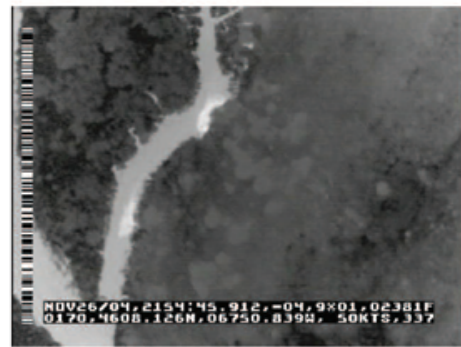

Number 3

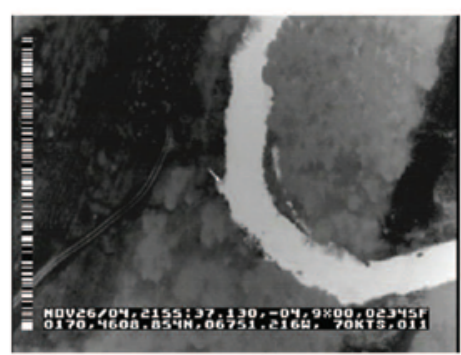

Number 6

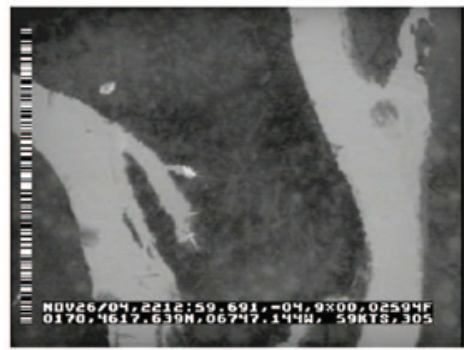

Number 9

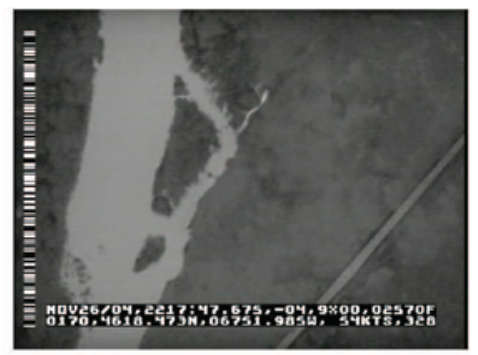

Number 12

Figure 6. Images of thermal anomalies for discharges into the Meduxnekeag River near Houlton, Maine, during the $A$, December 3-4, 2003, flight (images 61-72) and the $B$, November 26, 2004, flight (images 1-18). [Image numbers are anomalies described in tables 1 and 2.] —Continued 


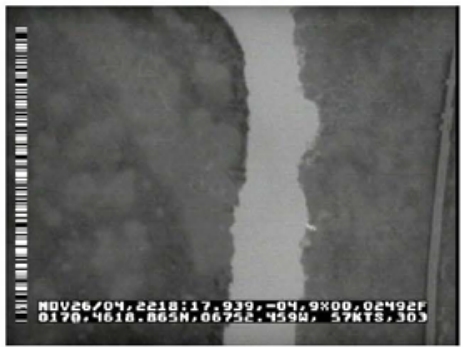

Number 13

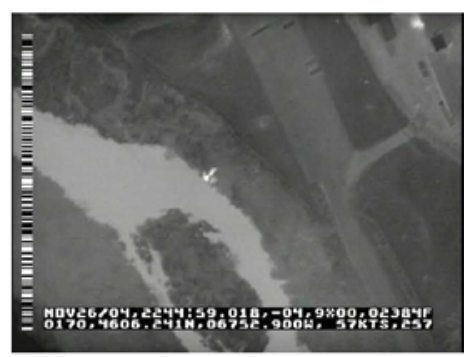

Number 16

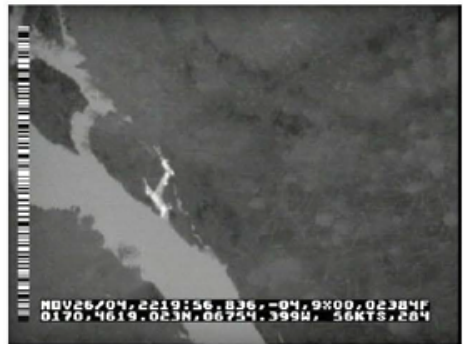

Number 14

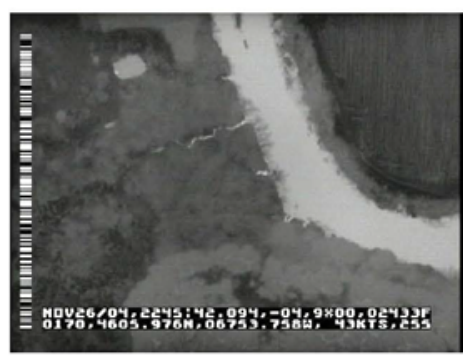

Number 17

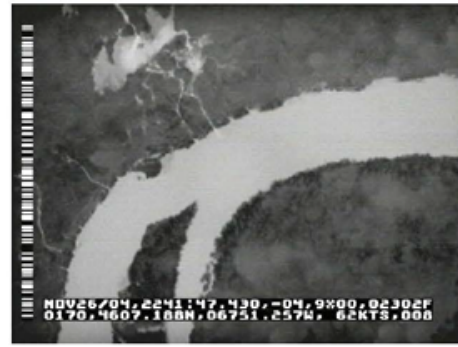

Number 15

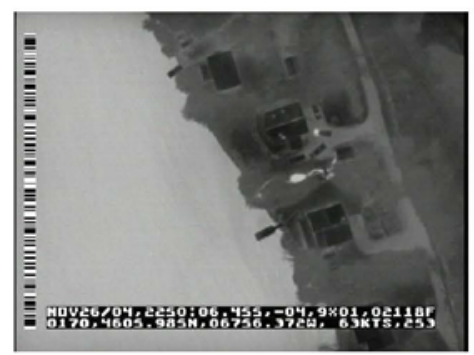

Number 18

Figure 6. Images of thermal anomalies for discharges into the Meduxnekeag River near Houlton, Maine, during the $A$, December 3-4, 2003, flight (images 61-72) and the $B$, November 26, 2004, flight (images 1-18). [Image numbers are anomalies described in tables 1 and 2.] —Continued 
Table 1. Thermal anomalies identified in the Meduxnekeag River near Houlton, Maine, during a flight on December 3 from 23:45 to 4:30 Eastern Standard Time on December 4, 2003.

[Latitude and longitude in degrees, minutes, and seconds (decimal seconds format). The anomalies are classified generally as GS, groundwater seep; WS, water seep from the ground at the edge of the water; and other, as noted after the anomaly's number. Each thermal anomaly is qualitatively described based on the size and magnitude of the changes in white intensity or brightness observed on the image. Definitions of abbreviations: NW-SE, northwest to southeast; $\mathrm{NE}$, northeast; NW, northwest; NE-SW, northeast to southwest; $\mathrm{N}-\mathrm{S}$, north to south]

\begin{tabular}{|c|c|c|c|c|}
\hline $\begin{array}{l}\text { Anomaly } \\
\text { number }\end{array}$ & Anomaly feature in figure 6 & Latitude & Longitude & Classification of thermal anomaly \\
\hline 61 & Bright feature near center of image & $46^{\circ} 05^{\prime} 55.62^{\prime \prime} \mathrm{N}$ & $68^{\circ} 00^{\prime} 30.60^{\prime \prime} \mathrm{W}$ & $\begin{array}{l}\text { GS or WS on shore of mostly frozen } \\
\text { Meduxnekeag Lake }\end{array}$ \\
\hline 62 & $\begin{array}{l}\text { Bright narrow feature at center of image with NW-SE } \\
\text { orientation }\end{array}$ & $46^{\circ} 06^{\prime} 05.94 " \mathrm{~N}$ & $67^{\circ} 52^{\prime} 17.82^{\prime \prime} \mathrm{W}$ & GS or WS at shoreline \\
\hline 63 & Bright feature in NE quadrant of image & $46^{\circ} 06^{\prime} 19.50^{\prime \prime} \mathrm{N}$ & $67^{\circ} 52^{\prime} 51.00^{\prime \prime} \mathrm{W}$ & GS or WS at shoreline \\
\hline 65 & Bright feature near center of image & $46^{\circ} 07^{\prime} 31.26^{\prime \prime} \mathrm{N}$ & $67^{\circ} 50^{\prime} 13.32^{\prime \prime} \mathrm{W}$ & $\begin{array}{l}\text { Storm water drain near building, east } \\
\text { side of bridge }\end{array}$ \\
\hline 66 & $\begin{array}{l}\text { Bright feature in NE quadrant of image, partially obscured by } \\
\text { bridge }\end{array}$ & $46^{\circ} 07^{\prime} 33.90^{\prime \prime} \mathrm{N}$ & $67^{\circ} 50^{\prime} 29.94^{\prime \prime} \mathrm{W}$ & $\begin{array}{l}\text { Storm water drain near building, west } \\
\text { side of bridge }\end{array}$ \\
\hline 67 & Long narrow, curved feature near center of image & $46^{\circ} 07^{\prime} 48.60^{\prime \prime} \mathrm{N}$ & $67^{\circ} 50^{\prime} 09.96^{\prime \prime} \mathrm{W}$ & $\begin{array}{l}\text { Drainage, possibly from intermittent or } \\
\text { small creek }\end{array}$ \\
\hline 68 & Narrow features at left center of image & $46^{\circ} 08^{\prime} 02.28^{\prime \prime} \mathrm{N}$ & $67^{\circ} 49^{\prime} 52.26^{\prime \prime} \mathrm{W}$ & GS from hillside \\
\hline 69 & Bright feature at right center of image & $46^{\circ} 08^{\prime} 07.38^{\prime \prime} \mathrm{N}$ & $67^{\circ} 49^{\prime} 45.54^{\prime \prime} \mathrm{W}$ & Possible GS or creek outlet to river \\
\hline 70 & Bright features near center of image & $46^{\circ} 08^{\prime} 24.00^{\prime \prime} \mathrm{N}$ & $67^{\circ} 49^{\prime} 21.30^{\prime \prime} \mathrm{W}$ & GS \\
\hline 71 & $\begin{array}{l}\text { Narrow feature in NW quadrant of image with NE-SW } \\
\text { orientation; also in NE quadrant of image with N-S orientation }\end{array}$ & $46^{\circ} 08^{\prime} 46.50^{\prime \prime} \mathrm{N}$ & $67^{\circ} 49^{\prime} 29.04^{\prime \prime} \mathrm{W}$ & $\begin{array}{l}\text { Discharge from wastewater-treatment } \\
\text { plant }\end{array}$ \\
\hline 72 & $\begin{array}{l}\text { Bright features at center and NE quadrant of image; long } \\
\text { narrow, curved feature at lower center to SE quadrant of image }\end{array}$ & $46^{\circ} 11^{\prime} 53.04 " \mathrm{~N}$ & $67^{\circ} 48^{\prime} 12.18^{\prime \prime} \mathrm{W}$ & GS; warm flowing surface water \\
\hline
\end{tabular}


Table 2. Thermal anomalies identified in the Meduxnekeag River near Houlton, Maine, during a flight on November 26, 2004, from 19:14 to 23:02 Eastern Standard Time.

[Latitude and longitude in degrees, minutes, and seconds (decimal seconds format). The anomalies are classified generally as GS, groundwater seep; WS, water seep from the ground at the edge of the water; and other, as noted after the anomaly's number. Each thermal anomaly was qualitatively described based on the size and magnitude of the changes in white intensity or brightness observed on the image. Definitions of abbreviations: SW-NE, southwest to northeast; NW, northwest; NW-SE, northwest to southeast; E-W, east to west]

\begin{tabular}{|c|c|c|c|c|}
\hline $\begin{array}{c}\text { Anomaly } \\
\text { number }\end{array}$ & Anomaly feature in figure 6 & Latitude & Longitude & Classification of thermal anomaly \\
\hline 1 & Bright features at center and NW quadrant of image & $46^{\circ} 07^{\prime} 37.00^{\prime \prime} \mathrm{N}$ & $67^{\circ} 50^{\prime} 34.04^{\prime \prime} \mathrm{W}$ & Two drains from buildings (65 and 66 in table 1 ) \\
\hline 2 & Bright feature near center of image & $46^{\circ} 07^{\prime} 59.97^{\prime \prime} \mathrm{N}$ & $67^{\circ} 50^{\prime} 48.08^{\prime \prime} \mathrm{W}$ & GS/creek-warm \\
\hline 4 & Bright features at center and upper center of image & $46^{\circ} 07^{\prime} 46.85^{\prime \prime} \mathrm{N}$ & $67^{\circ} 50^{\prime} 50.45^{\prime \prime} \mathrm{W}$ & GS at bank \\
\hline 5 & Narrow bright features at center of image & $46^{\circ} 07^{\prime} 56.04^{\prime \prime} \mathrm{N}$ & $67^{\circ} 50^{\prime} 48.08^{\prime \prime} \mathrm{W}$ & GS \\
\hline 6 & Bright feature at center of image & $46^{\circ} 08^{\prime} 51.42^{\prime \prime} \mathrm{N}$ & $67^{\circ} 51^{\prime} 12.61 " \mathrm{~W}$ & GS \\
\hline 8 & $\begin{array}{l}\text { Narrow faint white feature in the NW quadrant to } \\
\text { upper center of image }\end{array}$ & $46^{\circ} 17^{\prime} 07.52^{\prime \prime} \mathrm{N}$ & $67^{\circ} 47^{\prime} 01.42^{\prime \prime} \mathrm{W}$ & Creek with groundwater warmth \\
\hline 9 & Bright features near center of image & $46^{\circ} 17^{\prime} 39.16^{\prime \prime} \mathrm{N}$ & $67^{\circ} 47^{\prime} 07.94 " \mathrm{~W}$ & $\mathrm{GS}$ - minimum flow \\
\hline 11 & Bright features near center and upper center of image & $46^{\circ} 18^{\prime} 21.28^{\prime \prime} \mathrm{N}$ & $67^{\circ} 49^{\prime} 47.90^{\prime \prime} \mathrm{W}$ & GS at bank \\
\hline 12 & $\begin{array}{l}\text { Bright feature at upper center of image (SW-NE } \\
\text { orientation) }\end{array}$ & $46^{\circ} 18^{\prime} 28.14^{\prime \prime} \mathrm{N}$ & $67^{\circ} 52^{\prime} 00.53^{\prime \prime} \mathrm{W}$ & GS \\
\hline 16 & Bright feature at center of image & $46^{\circ} 06^{\prime} 19.89^{\prime \prime} \mathrm{N}$ & $67^{\circ} 52^{\prime} 52.21 " \mathrm{~W}$ & GS at bank (same feature as 63 in table 1 ) \\
\hline 17 & $\begin{array}{l}\text { Narrow bright feature with slight } \mathrm{E}-\mathrm{W} \text { orientation and } \\
\text { bright spot at center of image }\end{array}$ & $46^{\circ} 06^{\prime} 01.73^{\prime \prime} \mathrm{N}$ & $67^{\circ} 53^{\prime} 50.27^{\prime \prime} \mathrm{W}$ & Small creek discharge and GS near farm \\
\hline 18 & $\begin{array}{l}\text { Bright features at center to right center of image (other } \\
\text { bright spot is exhaust from a vehicle) }\end{array}$ & $46^{\circ} 05^{\prime} 58.86^{\prime \prime} \mathrm{N}$ & $67^{\circ} 56^{\prime} 22.05^{\prime \prime} \mathrm{W}$ & Unknown warm-water source near house on lake \\
\hline
\end{tabular}


Prepared by the Pembroke Publishing Service Center.

For more information concerning this report, contact:

Office Chief

U.S. Geological Survey

New England Water Science Center

Maine Office

196 Whitten Road

Augusta, ME 04330

dc_me@usgs.gov

or visit our Web site at:

http://me.water.usgs.gov 
